\title{
Intrabronchial instillation of paraquat in rats: lung morphology and retention study
}

\author{
I WYATT, ${ }^{1}$ A W DOSS, ${ }^{1}$ D C ZAVALA, ${ }^{2}$ AND L L SMITH ${ }^{1}$ \\ From the Central Toxicology Laboratory, ${ }^{1}$ Imperial Chemical Industries Ltd, Alderley Park, Nr Macclesfield, \\ Cheshire SK10 4TJ, UK, and Department of Medicine, ${ }^{2}$ University of Iowa College of Medicine, Iowa City, \\ Iowa 52242, USA
}

ABSTRACT Various amounts of paraquat $\left(10^{-5}\right.$ to $\left.10^{-12} \mathrm{~g}\right)$ in $0.1 \mathrm{ml}$ saline were instilled directly into the left bronchus of male adult rats. Gravimetric, macroscopic, and microscopic studies on the left lobe of the lung showed that $10^{-5} \mathrm{~g}$ of paraquat produced lung oedema and macroscopic lesions two and 14 days after dosing. The pathology of the lung was similar to that seen after systemic poisoning. When $10^{-6} \mathrm{~g}$ of paraquat was instilled, some animals developed lung oedema and macroscopic lesions. Microscopic examination showed subtle changes in the parenchyma of the lung. With amounts of paraquat equal to or less than $10^{-7} \mathrm{~g}$ (doses as little as $10^{-12} \mathrm{~g}$ were used), no changes in the lung were seen. This is contrary to published accounts in which amounts as low as $10^{-12} \mathrm{~g} \mathrm{(1} \mathrm{pg)}$ were reported to cause acute damage to the rabbit lung. When ${ }^{3} \mathrm{H}$ paraquat was instilled into the left lobe (doses of $10^{-5}$ to $10^{-10} \mathrm{~g}$ were used), the loss of paraquat from the lung was biphasic. The initial half-life was less than one hour. The secondary phase obeyed first-order kinetics, and the half-life was dependent on the dose of paraquat instilled. This half-life was as short as 11 hours when $10^{-5} \mathrm{~g}$ paraquat was instilled and was 76 hours after the instillation of $10^{-10} \mathrm{~g}$ paraquat. The decrease in the half-life of the secondary phase with increasing doses of paraquat is possibly associated with the production of oedema or lung cell damage, or both. After the instillation of $10^{-8} \mathrm{~g}{ }^{3} \mathrm{H}$ paraquat, the initial half-life was less than 15 minutes, and paraquat was detected in the urine and plasma at that time. This suggests that $50 \%$ of the instilled paraquat was rapidly absorbed from the lung into the plasma.

Paraquat $\left(1,1^{\prime}\right.$-dimethyl-4,4'-bipyridilium) is a widely used non-selective contact herbicide; toxic effects in experimental animals include damage to the liver, kidney, adrenal, and thymus, but the most characteristic feature of paraquat toxicity is lung damage. ${ }^{1}$ Several species including the mouse, rat, dog, and monkey have been shown to be susceptible to lung damage after a single oral, subcutaneous, or intraperitoneal dose. 12 The rabbit, however, did not develop a lung lesion after a single dose $^{3}{ }^{4}$ although lung lesions, similar to those described in rats, were reported in rabbits after a multiple dosing regimen. ${ }^{5}$ Of the species investigated, the rat is by far the most extensively studied. ${ }^{6-14}$ Most authors agree that the lung lesion is biphasic; a destructive phase associated with alveolar epithelial cell damage, oedema, haem-

Requests for reprints to: Dr L L Smith.

Received 28 November 1979

Accepted 11 August 1980 orrhage, and inflammation being followed by a "reparative" phase dominated by hypercellularity, fibrosis, and collagen deposition. Both these phases cause anoxia which, if severe enough, will result in the death of the animal. It is, therefore, generally accepted that paraquat falls into a small class of chemicals that produce severe lung damage after systemic poisoning. Four studies have been reported describing the topical administration of paraquat into the lung. Gage ${ }^{15}$ claimed that rats exposed to high concentrations of respirable particles of paraquat develop the "damaging phase" but not the "reparative phase," while Kimbrough and Gaines showed that $50 \mu \mathrm{g} / \mathrm{kg}$ paraquat instilled into the rat lung produced fibrosis and epithelial proliferation seven days after dosing. Seidenfeld et al $^{\mathbf{1 6}}$ in a more recent inhalation study with respirable paraquat reported "typical" paraquat lung lesions in rabbits, although the doses required were large and given on a weekly basis over many weeks. Furthermore, 
Zavala and Rhodes ${ }^{17}$ reported that the single instillation of $1 \mathrm{pg}$ directly into the rabbit lung caused acute localised damage within three days. The present studies were undertaken to $(a)$ determine if the rat lung was as susceptible to instilled paraquat as the rabbit lung, and (b) determine the concentration of instilled paraquat needed to produce histopathological damage.

\section{Materials and methods}

\section{SPECIAL MATERIALS}

$\left({ }^{3} \mathrm{H}\right.$ methyl) paraquat dichloride $(3 \mathrm{Ci} / \mathrm{mmol})$ was purchased from the Radiochemical Centre, Amersham. Paraquat dichloride (roughly $99 \%$ pure) was provided by Plant Protection Ltd, ICI Ltd. Halothane was provided by Pharmaceuticals Division, ICI Ltd. Soluene 350 (a tissue solubiliser), Instagel and Dimilume (scintillation cocktails) were all purchased from Packard Instruments Ltd.

ANIMALS

Alderley Park Wistar-derived SPF male rats (body weight $180-200 \mathrm{~g}$ ) were used for all studies.

\section{DOSING SOLUTIONS}

Since low concentrations of paraquat will bind to glassware all dosing solutions were kept in plastic containers, and all manipulations were carried out using plastic equipment. A plastic cannula and syringe were used to instil paraquat into the rat's lung. All paraquat dosing solutions studied were prepared so that the required concentration of paraquat was in $0.1 \mathrm{ml}$ of saline: $10^{-8} \mathrm{~g}$ and $10^{-10} \mathrm{~g}{ }^{3} \mathrm{H}$ paraquat dosing solutions were prepared directly from the material bought from Amersham, while $10^{-5}$, $10^{-6}$, and $10^{-7} \mathrm{~g}^{3} \mathrm{H}$ paraquat dosing solutions contained $10^{-8} \mathrm{~g}^{3} \mathrm{H}$ paraquat. Because of the possibility of binding, $0.1 \mathrm{ml}$ of the ${ }^{3} \mathrm{H}$ paraquat dosing solutions were taken at three separate intervals, at the beginning, middle, and end of the period in which animals were being dosed, and dispensed into a plastic scintillation vial containing $100 \mu \mathrm{g}$ paraquat ion in $1.0 \mathrm{ml} \mathrm{H}_{2} \mathrm{O}$. Ten millilitres of Instagel were added and the radioactivity measured.

\section{INSTILLATION PROCEDURE}

The rats were weighed before being anaesthetised with halothane ( $3 \%$ in oxygen). The anaesthetic concentration was controlled by a Fluotec (Cyprane Ltd) incorporated into a device for administering anaesthetics to small rodents (Pharmaceuticals Division, ICI Ltd), and anaesthesia was maintained throughout the operation. An incision was made to disclose the trachea and a small cut made between two cartilage segments of the trachea. The plastic cannula (length $30 \mathrm{~mm}$, width $2 \mathrm{~mm}$ ) attached to the syringe was inserted into the trachea and passed into the left bronchus. Previous experience with this technique, using a vital dye, had shown that the cannula does enter the left bronchus. The contents of the syringe were instilled directly into the left bronchus, the cannula withdrawn, and the cut in the trachea stitched (one stitch only) as was the incision. The rat was allowed to recover and given access to food and water.

INSTILLATION, DISTRIBUTION AND

RETENTION OF ${ }^{3}$ H PARAQUAT IN THE RAT LUNG

Paraquat was directly instilled into the left bronchus in amounts of $10^{-5}, 10^{-6}, 10^{-7}, 10^{-8}$, or $10^{-10} \mathrm{~g}$ in $0.1 \mathrm{ml}$. For each concentration of paraquat instilled, three rats were killed with halothane at $1,3,6,24$, 48 , and 72 hours after dosing. For each concentration of paraquat studied, there were three unoperated control rats and three sham-operated rats as controls, into the lungs of which $0.1 \mathrm{ml}$ saline was instilled. These animals were killed one hour after instillation. After the death of each rat, the abdomen was opened and the hepatic artery severed. The heart and lungs were removed and the lobes of the lung divided into the following groups for each animal, (a) left lobe, $(b)$ posterior lobe (large right lobe), and (c) the remaining three lobes.

The lobes were blotted, inspected for macroscopic lesions, and weighed. They were then placed in individual glass scintillation vials containing $\mathbf{1 0 0}$ $\mu \mathrm{g}$ of paraquat ion to reduce any binding to glass. Two millilitres of Soluene 350 were added, the lung tissue dissolved on a water bath at $50^{\circ} \mathrm{C}$, and $20 \mathrm{ml}$ of Dimilume scintillator were added. The contents of the vial were mixed and then stored in the dark in a cold room for four days to reduce chemiluminescence. The radioactivity was determined using a liquid scintillation counter. The counting efficiencies of the dosing solutions and lung samples were determined by the addition of an internal standard of known radioactivity. The results were converted to disintegrations per minute per lobe of lung, and the amount of paraquat in each lobe was expressed as a percentage of the total paraquat in the lung. The specific activity of the dosing solution was used to calculate the amount of paraquat present in the lung.

DISTRIBUTION OF ${ }^{3}$ H PARAQUAT IN THE RAT Throughout these studies, the determination of ${ }^{3} \mathrm{H}$ label was used as a measure of the amount of paraquat present in the tissue. This was done on the basis that $(a)$ there is no evidence of metabolism of paraquat in rats, ${ }^{18}$ and $(b)$ the determination of the amount of paraquat in tissues using ${ }^{14} \mathrm{C}$ labelled 
paraquat (C atom to which ${ }^{3} \mathrm{H}$ label is attached) or a colorimetric assay that is specific for paraquat, gives identical results (I Mills, unpublished data). It is assumed that there was no ${ }^{3} \mathrm{H}$ exchange from the ${ }^{3} \mathrm{H}$ paraquat while it was in the body of the animal.

Paraquat $\left(10^{-8} \mathrm{~g}\right.$ in $\left.0.1 \mathrm{ml}\right)$ or saline $(0.1 \mathrm{ml})$ was instilled into the lungs of rats, and the distribution of paraquat into the body fluids and organs of the rat were studied at 15 and 60 minutes. There were six rats per group and per time point. Immediately after instillation the rats were housed in individual metabolism cages, so that the urine could be collected. Before killing the rats with halothane, they were induced to urinate by lifting their tails. On death, the following body fluids and organs were removed and prepared for the determination of radioactivity (all scintillation vials contained $100 \mu \mathrm{g}$ of paraquat) as described:

Blood-Three millilitres of blood were taken by heart puncture, placed in a lithium heparin tube, and the plasma separated. One millilitre of plasma was added to a plastic scintillation vial and $10 \mathrm{ml}$ of Instagel were added.

Urine-The metabolism cages were rinsed with 1.0 $\mathrm{ml}$ of water containing $100 \mu \mathrm{g}$ of paraquat, and the contents of the urine collector were transferred to a plastic scintillation vial. Ten millilitres of Instagel were added to each sample.

Kidneys-The left and right kidneys were removed, blotted, and each kidney was weighed and transferred to a glass scintillation vial. Three millilitres of Soluene 350 were added to each vial, and the tissue dissolved on a water bath at $50^{\circ} \mathrm{C}$. Once the sample was solubilised, the volume was noted, $2 \mathrm{ml}$ was transferred to another glass scintillation vial and 20 $\mathrm{ml}$ of Dimilume added. The samples were stored at $4^{\circ} \mathrm{C}$ in the dark.

Trachea-The part of the trachea taken was that lying below the point of the insertion of the cannula down to the lung lobes. It was placed in a glass scintillation vial and $2 \mathrm{ml}$ of Soluene 350 was added. The tissue was solubilised on a water bath at $50^{\circ} \mathrm{C}$. When dissolved, $20 \mathrm{ml}$ Dimilume was added and the samples stored at $4^{\circ} \mathrm{C}$ in the dark.

Lung-The lung was processed as previously described.

The radioactivity in the urine, plasma, and organ samples was measured in a liquid scintillation counter. The organ samples were left in the dark at $4^{\circ} \mathrm{C}$ for four days before the radioactivity was determined. The counting efficiencies of all samples were determined by the addition of internal standard. Using the specific activity of the dosing solution, the amount of paraquat in the plasma, urine, and organs was calculated. We have assumed that initially paraquat distributes in the body water, and on this basis we have used the concentration in the plasma to calculate the amount in body water.

\section{MACROSCOPIC AND MICROSCOPIC \\ EXAMINATION}

For each concentration of paraquat instilled, six rats were used and the concentrations of paraquat instilled were $10^{-5}, 10^{-6}, 10^{-7}, 10^{-8}, 10^{-10}$, and $10^{-12} \mathrm{~g}$ in $0.1 \mathrm{ml}$. Controls consisted of six unoperated rats and 12 sham-operated rats (which received $0.1 \mathrm{ml}$ saline). Half the rats in each group were killed two days after dosing, and the remainder at 14 days. The rats were killed with halothane and the heart and lungs were removed. The lungs were inspected for macroscopic damage, and then fixed for histological examination by inflating them, via the trachea, with unbuffered formol saline (about $2.5 \mathrm{ml} / 100 \mathrm{~g}$ body weight) from a syringe. The trachea was tied off, and the lungs were submerged in formol saline. When fixed, the left lobe was divided transversely into three portions, and all three portions from each lung were embedded in one paraffin block. Serial $5 \mu$ thick paraffin sections were prepared, every 50th section being stained with haematoxylin and eosin.

\section{Results}

MACROSCOPIC AND WET WEIGHT CHANGES

The instillation of $10^{-5} \mathrm{~g}$ paraquat caused macroscopic damage only to the left lobe of the lung of the treated rats. This was first apparent $24 \mathrm{~h}$ after dosing and about $50 \%$ of each left lobe was affected. The damage increased with time so that by $72 \mathrm{~h}$ the left lobe of all three treated rats was of a plum-coloured jelly-like consistency. The lesion was much less extensive in those lungs into which $10^{-6} \mathrm{~g}$ paraquat had been instilled. The damage was restricted to the left lobe, was patchy, and did not increase between 24 and $72 \mathrm{~h}$. After the instillation of $10^{-7} \mathrm{~g}$ paraquat into the left bronchus, only one macroscopic lesion was observed $48 \mathrm{~h}$ after dosing, which may have been the result of paraquat. That paraquat was responsible is uncertain, however, since in two rats given $10^{-7} \mathrm{~g}$ paraquat, one of the lungs appeared abnormally large at $48 \mathrm{~h}$ and the other at $72 \mathrm{~h}$. As all of the lobes were affected it is unlikely that the increased size of the lung was a result of the instillation of paraquat. Also, these changes were not typical of paraquat damage and may have reflected the presence of Sendai virus infection, which was identified in our colony within a few weeks of the completion of this study. Furthermore, an additional study was carried out in which $10^{-7} \mathrm{~g}$ paraquat was instilled into the left bronchus and the wet weight and percentage water in the left lobe compared with control rats given saline. No increase in either wet weight or per- 
Table 1 The mean wet weight of the left lung lobe (mg) after instillation of ${ }^{3} \mathrm{H}$ paraquat (adjusted for bodyweight)

\begin{tabular}{|c|c|c|c|c|c|}
\hline \multirow[t]{2}{*}{ Time of death $(h)$} & \multicolumn{5}{|c|}{ Treatment } \\
\hline & $10^{-5}$ & $10^{-6}$ & $10^{-7}$ & $10^{-8}$ & $10^{-10}$ \\
\hline 0 (Controls) & $\begin{array}{l}352 \\
(6)\end{array}$ & $\begin{array}{l}356 \\
(6)\end{array}$ & $\begin{array}{l}400 \\
(5)\end{array}$ & $\begin{array}{l}389 \\
(12)\end{array}$ & $\begin{array}{l}385 \\
(6)\end{array}$ \\
\hline 1 & $\begin{array}{l}383 \\
(3)\end{array}$ & $\begin{array}{l}413 \\
\text { (3) }\end{array}$ & $\begin{array}{l}348 \\
(3)\end{array}$ & $\begin{array}{l}379 \\
(6)\end{array}$ & $\begin{array}{l}351 \\
(3)\end{array}$ \\
\hline 3 & $\begin{array}{l}347 \\
\text { (3) }\end{array}$ & $\begin{array}{l}411 \\
(3)\end{array}$ & $\begin{array}{l}304 \\
(2)\end{array}$ & $\begin{array}{l}344 \\
(6)\end{array}$ & $\begin{array}{l}376 \\
(3)\end{array}$ \\
\hline 6 & $\begin{array}{l}383 \\
(3)\end{array}$ & $\begin{array}{l}421^{* *} \\
(3)\end{array}$ & $\begin{array}{l}347 \\
(3)\end{array}$ & $\begin{array}{l}360 \\
(6)\end{array}$ & $\begin{array}{l}378 \\
(3)\end{array}$ \\
\hline 24 & $\begin{array}{l}491^{*} \\
(3)\end{array}$ & $\begin{array}{l}411 \\
\text { (3) }\end{array}$ & $\begin{array}{l}361 \\
(3)\end{array}$ & $\begin{array}{l}361 \\
(6)\end{array}$ & 345 \\
\hline 48 & $\begin{array}{l}593^{*} \\
(3)\end{array}$ & $\begin{array}{l}499^{*} \\
(3)\end{array}$ & $\begin{array}{l}477 \\
\text { (3) }\end{array}$ & $\begin{array}{l}376 \\
\text { (3) }\end{array}$ & $\begin{array}{l}373 \\
(3)\end{array}$ \\
\hline Dimger & $\begin{array}{l}674^{*} \\
(3)\end{array}$ & $\begin{array}{l}529^{*} \\
(3)\end{array}$ & $\begin{array}{l}498^{* *} \\
(3)\end{array}$ & $\begin{array}{l}378 \\
(2)\end{array}$ & $\begin{array}{l}394 \\
(3)\end{array}$ \\
\hline $\begin{array}{l}\text { Difference needed } \\
\text { for a significance } \\
\text { at } 5 \% \text { level } \\
\text { compared with } \\
\text { controls }\end{array}$ & 58 & 57 & 94 & 28 & 31 \\
\hline \multicolumn{6}{|c|}{$\begin{array}{l}\text { Lungs of rats were instilled with } 10^{-5}, 10^{-6}, 10^{-7}, 10^{-8}, 10^{-10} \mathrm{~g}^{3} \mathrm{H} \\
\text { paraquat and the wet weight of the lung lobes determined at } 0,1,3,6 \text {, } \\
24,48 \text {, and } 72 \mathrm{~h} \text {. Results are expressed as mean with number of animals } \\
\text { studied in parentheses. All data on wet weight of left lung for each } \\
\text { individual dose were considered together by analysis of covariance on } \\
\text { final body weight. The t-tests have been based on error variance } \\
\text { from this analysis. } \\
\text { *Significantly different from control left lung weight at the } 0 \cdot 1 \% \text { level. } \\
\text { **Significantly different from control left lung weight at } 5 \% \text { level. }\end{array}$} \\
\hline
\end{tabular}

centage water was found, indicating that the effect seen in the original study was spurious and probably associated with lung disease.

After the instillation of $10^{-5} \mathrm{~g}$ paraquat, only the left lobe of the lung increased in weight (table 1). The wet weights of the left lobe of the lung increased with time and were significantly different (at the $0.1 \%$ level) from controls at 24, 48, and $72 \mathrm{~h}$ (table 1). A similar result was obtained after the instillation of $10^{-6} \mathrm{~g}$ paraquat but to a lesser extent, with significant weight increases (at the $0.1 \%$ level) found by 48 and $72 \mathrm{~h}$ (table 1). Only at 72 hours after the instillation
Table 2 Distribution of ${ }^{3} \mathrm{H}$ paraquat found in lung lobes expressed as percentage of total ${ }^{3} \mathrm{H}$ paraquat in lung

\begin{tabular}{|c|c|c|c|}
\hline \multirow[t]{2}{*}{ Treatment } & \multicolumn{3}{|c|}{ Lung lobes $(\% \pm S E M)$} \\
\hline & Left & Posterior & Rest \\
\hline $\begin{array}{l}10^{-5} \mathrm{~g}(18) \\
10^{-6} \mathrm{~g}(18) \\
10^{-7} \mathrm{~g}(18) \\
10^{-8} \mathrm{~g}(30) \\
10^{-10} \mathrm{~g}(18)\end{array}$ & $\begin{array}{l}81 \cdot 1 \pm 4 \cdot 7 \\
89.8 \pm 2.4 \\
71 \cdot 7 \pm 6 \cdot 1 \\
75 \cdot 5 \pm 4 \cdot 0 \\
82.7 \pm 3 \cdot 5\end{array}$ & $\begin{array}{r}10.0 \pm 2.5 \\
4.6 \pm 1.1 \\
16.9 \pm 3.9 \\
14.7 \pm 2.6 \\
10.5 \pm 3.4\end{array}$ & $\begin{array}{r}8.9 \pm 2.4 \\
5.6 \pm 1.4 \\
11.4 \pm 2.9 \\
9.9 \pm 1.8 \\
6.5 \pm 1.4\end{array}$ \\
\hline
\end{tabular}

Lungs of rats were instilled with $10^{-5}, 10^{-6}, 10^{-7}, 10^{-8}$, and $10^{-10} \mathrm{~g}$ ${ }^{3} \mathrm{H}$ paraquat and its distribution in lung was calculated as percentage of total paraquat present.

of $10^{-7} \mathrm{~g}$ paraquat was there a significant increase in the wet weight. This, as discussed above, was probably the consequence of viral disease in the colony. No changes were found when $10^{-8} \mathrm{~g}$ or $10^{-10} \mathrm{~g}$ of paraquat was instilled (table 1).

DISTRIBUTION AND RETENTION OF PARAQUAT For all doses of ${ }^{3} \mathrm{H}$ paraquat instilled into the lungs, about $80 \%$ of the paraquat that could be found in the lung was in the left lobe (table 2). The remaining paraquat was fairly evenly distributed between the posterior right and remaining lobes (table 2). Nevertheless, examination of the individual data contained in table 2, showed that in some rats as little as $40 \%$ of the paraquat present was in the left lobe. For this reason, the retention of paraquat in the lung with time has been expressed on a whole lung basis (table 3).

About $50 \%$ of the paraquat instilled into the lung (for all doses) was present in the lung $1 \mathrm{~h}$ after dosing (table 3). For all concentrations of paraquat there were at least two phases of paraquat clearance from the lung; a phase in which paraquat was cleared rapidly followed by a much slower phase that appeared to obey first-order kinetics between 6 and $72 \mathrm{~h}$. The half-life of paraquat in the lung was determined in the elimination phase, using the least squares

Table 3 Paraquat lung levels after instillation of ${ }^{3} \mathrm{H}$ paraquat (percentage of initial dose)

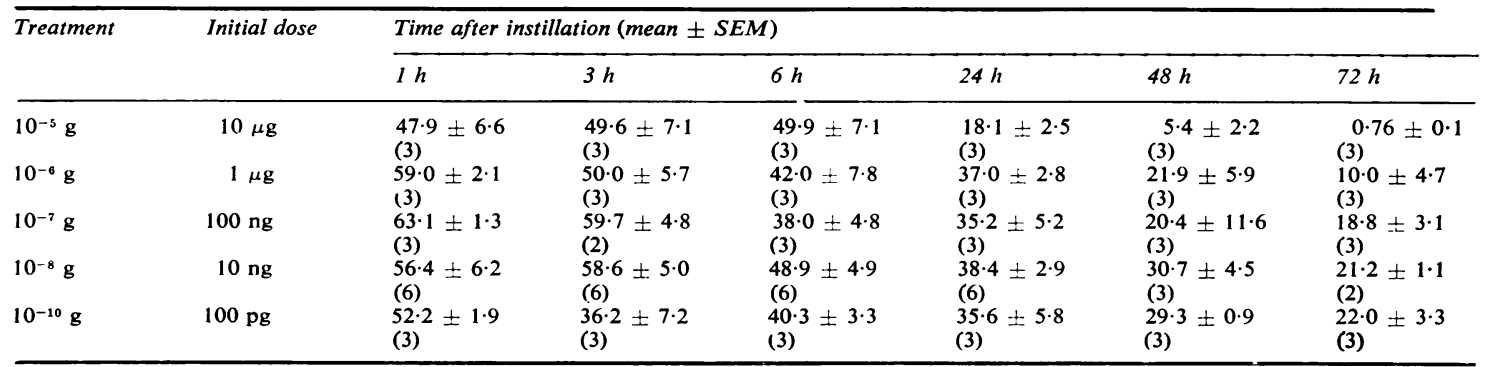

Lungs of rats were instilled with $10^{-5}, 10^{-6}, 10^{-7}, 10^{-8}$ and $10^{-10} \mathrm{~g}{ }^{3} \mathrm{H}$ paraquat and amount present in lung determined using radiochemical measurements. (Number of animals studied in parentheses.) 
Table 4 Elimination half-life of paraquat in rat lung after instillation

\begin{tabular}{lll}
\hline Treatment & Mean $t \frac{1}{2}(h)$ & $95 \%$ Confidence limits \\
\hline $10^{-5} \mathrm{~g}$ & 11 & $10-13$ \\
$10^{-8} \mathrm{~g}$ & 28 & $20-51$ \\
$10^{-7} \mathrm{~g}$ & 53 & $28-705$ \\
$10^{-8} \mathrm{~g}$ & 58 & $42-95$ \\
$10^{-10} \mathrm{~g}$ & 76 & $53-133$ \\
\hline
\end{tabular}

Lungs of rats were instilled with $10^{-5}, 10^{-6}, 10^{-7}, 10^{-8}$, and $10^{-10} \mathrm{~g}$ ${ }^{3} \mathrm{H}$ paraquat. Half-life of its elimination from lung was calculated using least squares method of analysis on log concentration of paraquat retained in lung at $6,24,48$, and $72 \mathrm{~h}$ for each dose instilled. Slope per hour obtained was converted into half-life using $t_{\frac{1}{2}}=\frac{\log 2}{\text { Slope }}$. Results are expressed as mean t $\frac{1}{2}$ with $95 \%$ confidence limits. For $10^{-5}$ $10^{-6}, 10^{-7}$, and $10^{-10} \mathrm{~g}^{3} \mathrm{H}$ paraquat instilled, three rats per time point were investigated, while for $10^{-8} \mathrm{~g}^{3} \mathrm{H}$ paraquat there were six rats at six and $24 \mathrm{~h}$, three rats at $48 \mathrm{~h}$, and two rats at $72 \mathrm{~h}$.

method of analysis on the log concentration of paraquat in the lung at $6,24,48$, and $72 \mathrm{~h}$ (table 4 ). The half-lives varied from $11 \mathrm{~h}$ when $10^{-5} \mathrm{~g}$ paraquat was instilled, to 76 hours with $10^{-10} \mathrm{~g}$ paraquat (table 4). Thus there was an apparent relationship between the half-life for this slow phase and the amount of paraquat instilled (table 4).

Fifteen minutes after the instillation of $10^{-8} \mathrm{~g}$ of ${ }^{3} \mathrm{H}$ paraquat, about $90 \%$ of the bipyridyl could be accounted for in the tissues examined, with only $50 \%$ present in the lung (table 5). One hour after instillation, $75 \%$ of the paraquat was accounted for with $50 \%$ present in the lung (table 5). Significant amounts of paraquat were found in the plasma and urine (table 5).

\section{HISTOLOGICAL EXAMINATION}

In this study about 75 sections taken from each left lobe were examined under the light microscope. Only in the left lobes taken from lungs instilled with $10^{-5} \mathrm{~g}$ of paraquat was there evidence of pathological change. Two days after dosing with $10^{-5} \mathrm{~g}$, all three lungs examined showed gross macroscopic lesions. Histologically there was perivascular oedema and polymorphonuclear infiltration in two of the three lungs examined. In some sections taken from the left lobe of the third rat there was the alveolar wall thickening, collapse of the alveoli, pronounced, congestion and perivascular oedema typical of an acute paraquat lesion. By 14 days one rat dosed with $10^{-5} \mathrm{~g}$ paraquat had pleural thickening. Another rat given $10^{-5} \mathrm{~g}$ paraquat had alveolar wall thickening, peribronchiolar and perivascular oedema, congestion, and early fibrosis in the form of proliferating fibroblasts; this is typical of the proliferative phase of the paraquat lesion. Two days after dosing with $10^{-6} \mathrm{~g}$ paraquat, some sections taken from the left lobe showed incieased numbers of neutrophil polymorphs in the perivascular region and focal alveolar wall thickening consistent with an acute but mild paraquat lesion. Lungs taken from rats given $10^{-7}, 10^{-8}$, and $10^{-12} \mathrm{~g}$ did not show any histological evidence of paraquat-induced changes. Sections taken from the lungs of rats given $10^{-5}, 10^{-6}, 10^{-8}$, and $10^{-12} \mathrm{~g}$ paraquat as well as those taken fromcontrols showed the varying degrees of peribronchiolar and perivascular infiltration that form part of the background pathology of rats used in our laboratory.

\section{Discussion}

The technique used for the instillation of paraquat into the left lobe of the rat lung was similar to that described by Enna and Schanker ${ }^{19}$ except that we attempted to place the cannula in the left bronchus. Roughly $80 \%$ of the paraquat subsequently detected in the lung was found in the left lobe (table 2). In some rats, however, a considerable proportion of the paraquat was found in the right lobes. This may have been caused by the cannula not passing into the left bronchus or a "blow back" of the instilled fluid into the trachea and right bronchus immediately after instillation. To minimise these spurious results, we have chosen to present the retention of paraquat data on a per-whole-lung basis. Provided the data presented in table 2 for the instillation of ${ }^{3} \mathrm{H}$ paraquat reflect the distribution of paraquat in the gravimetric, macroscopic, and microscopic studies, then there is a reasonable basis for confining the microscopic examination of the lung to the left lobe. Also, with the exception of two lungs showing macroscopic changes

Table 5 Distribution of $10^{-8} \mathrm{~g}^{3} \mathrm{H}$ paraquat $(10 \mathrm{ng})$ in the rat after instillation into left lung

\begin{tabular}{|c|c|c|c|c|c|c|c|}
\hline \multirow{2}{*}{$\begin{array}{l}\text { Time after } \\
\text { instillation }\end{array}$} & \multicolumn{7}{|c|}{$n g$ Paraquat ion $\pm S E M$} \\
\hline & Plasma $(/ m l)$ & Total $\mathrm{H}_{2} \mathrm{O}$ & Lung & Trachea & Kidney & Urine & $\%$ Recovery \\
\hline $\begin{array}{l}15(6) \\
60(5)\end{array}$ & $\begin{array}{l}0.02545 \pm 0.00496 \\
0.00924 \pm 0.0010\end{array}$ & $\begin{array}{l}3.46 \pm 0.68 \\
1.25 \pm 0.13\end{array}$ & $\begin{array}{l}4.99 \pm 0.28 \\
5.2 \pm 0.45\end{array}$ & $\begin{array}{l}0.118 \pm 0.042 \\
0.152 \pm 0.025\end{array}$ & $\begin{array}{l}0.150 \pm 0.042 \\
0.052 \pm 0.007\end{array}$ & $\begin{array}{l}0.173 \pm 0.047 \\
0.822 \pm 0.23\end{array}$ & $\begin{array}{l}88.9 \pm 6.3 \\
74.8 \pm 2.5\end{array}$ \\
\hline
\end{tabular}

Lungs of rats were instilled with $10^{-8} \mathrm{~g}{ }^{3} \mathrm{H}$ paraquat and radiochemical techniques determined its distribution in organs and fluids of each rat. Amount of paraquat in plasma was corrected to amount in total body water, using a factor of 136 . For percentage recovery we used total body water concentration. Amount of paraquat present in organs and fluids is expressed as mean \pm SEM with number of animals studied in parentheses. (Total body water of a mature rat $=680 \mathrm{~g} / \mathrm{kg}$; Biological Data Book. 2nd ed. Vol III, p 1990, Fed Am Soc Exp Biol. The rats weighed 200 g.) 
unlike that of a paraquat lesion, no macroscopic changes were seen in any of the right lobes examined in the treated rats.

To carry out the microscopic examination of the lung, a section through the left lobe was examined every $250 \mu$. We did this since in the rabbit instillation study of Zavala and Rhodes, ${ }^{17}$ petechial lesions about $1 \mathrm{~mm}$ in size were observed a few days after the instillation of $10^{-12} \mathrm{~g}(1 \mathrm{pg})$ of paraquat.

The results of our study showed that the instillation of $10^{-5} \mathrm{~g}$ or $10^{-6} \mathrm{~g}$ of paraquat into the left lobe of the lung of the rat caused macroscopic lesions and an increase in the weight of the left lobe of the lung (table 1). We have subsequently shown that these changes are the result of an increase in the water content of the lung (I Wyatt and L L Smith, unpublished data). Microscopic examination of the left lobe of the lung taken from rats dosed with $10^{-6} \mathrm{~g}$ of paraquat showed abnormalities consistent with a paraquat lung lesion at two and 14 days after dosing. Those treated with $10^{-7} \mathrm{~g}$ paraquat were indistinguishable from controls. Thus when the gravimetric, macroscopic, and microscopic observations are considered together we can conclude that amounts of paraquat of $10^{-7} \mathrm{~g}$ or less, instilled into the left lobe, do not cause lung damage.

The retention of paraquat in the lung after instillation of $10^{-5}, 10^{-6}, 10^{-7}, 10^{-8}$, and $10^{-10} \mathrm{~g}$ of paraquat showed a biphasic response with roughly $50 \%$ of the paraquat eliminated within $1 \mathrm{~h}$ after dosing (table 3). When $10^{-8}{ }^{3} \mathrm{H}$ paraquat was instilled, significant amounts of paraquat were found in the total water, kidney, and urine 15 minutes and $1 \mathrm{~h}$ after dosing. This suggests that the rapid elimination of $50 \%$ of the instilled dose is the result of uptake into the blood stream from which it redistributes in the body tissues and is excreted in the urine. After this fast clearance, the elimination rate of paraquat from the lung increased with decreasing doses from $11 \mathrm{~h}$ with $10^{-5} \mathrm{~g}$ to $76 \mathrm{~h}$ with $10^{-10} \mathrm{~g}$ (table 4). It is possible that this dose-dependent elimination rate was the consequence of the extent of damage that a particular dose of paraquat produces. With large doses $\left(10^{-5}, 10^{-6} \mathrm{~g}\right)$, the presence of oedema and cell damage may increase the clearance of paraquat from the lung either by expectoration or by absorption into the blood stream.

What emerges clearly from these studies is that after the direct instillation of $10^{-7} \mathrm{~g}$ paraquat $(100$ ng) to the left lobe, there is no gravimetric, macroscopic, or microscopic evidence of lung damage. This is despite the fact that paraquat can be detected in the lung (63 ng/whole lung) one hour after dosing (table 3) with a half-life for the secondary phase of $53 \mathrm{~h}$ (table 4). It is of interest that the $t_{\frac{1}{2}}$ for the efflux of paraquat in the rat lung in vivo after in- travenous dosing of an approximate LD50 dose is about $24 \mathrm{~h}^{.20}$ With doses of $10^{-7} \mathrm{~g}$ paraquat or lower, no evidence of lung damage was found, although paraquat could be detected in the lung $72 \mathrm{~h}$ after instillation of as little as $10^{-10} \mathrm{~g}(100 \mathrm{pg})$ of paraquat. The conclusion that the rat can tolerate the instillation of $10^{-7} \mathrm{~g}(100 \mathrm{ng})$ of paraquat without sustaining lung damage is consistent with the observation that $24 \mathrm{~h}$ after subcutaneous dosing of $5 \mathrm{mg}$ paraquat $/ \mathrm{kg}$ to rats, the concentration of paraquat in the lung was about $1.5 \mu \mathrm{g} / \mathrm{g}$ wet weight and there were no microscopical or ultrastructural changes in the lung (I Pratt et al, unpublished data). The resulrs reported here for the effects of paraquat instilled directly into rat lung differ considerably from those reported by Zavala and Rhodes. ${ }^{17}$

There are two major differences between our studies and those of Zavala and Rhodes. ${ }^{17}$ Firstly, their studies used rabbits whereas we have used rats. We chose rats on the basis that they are known to be susceptible to lung damage after the systemic administration of paraquat and because much more is knownabout the response of the rat lung to paraquat than about the rabbit lung. Certainly, the results from our studies suggest that the response in the rat lung after instillation of paraquat is similar to that produced by systemic poisoning. Secondly, although both our studies and those of Zavala and Rhodes were conducted by instillation the procedures were different. At best, in our hands the cannula would enter the left bronchus, whereas in the procedure described by Zavala and Rhodes, ${ }^{21}$ the catheter passes further down the respiratory tree into a peripheral segmental bronchus. This may have the effect of instilling higher concentrations of paraquat into a given volume of rabbit lung parenchyma compared with the procedure used in the rat. On the other hand, the left lobe of the lung of the rat weighs roughly $300 \mathrm{mg}$ whereas the lobe catheterised in the rabbit probably weighs 1.5 to $2 \mathrm{~g}$. Thus possibly the difference in techniques does not fully explain the very large difference between our results and those of Zavala and Rhodes. ${ }^{17}$ The apparent "hyper-susceptibility" of the rabbit lung to directly instilled paraquat reported by Zavala and Rhodes is also curiously at variance with the lack of sensitivity of rabbit lung to paraquat when it is dosed by other routes. ${ }^{3} 416$

In conclusion these studies show that after the instillation of $10^{-7} \mathrm{~g}$ or less of paraquat directly into the left lobe of the rat lung there is no evidence of lung damage despite the presence of paraquat in the lung for periods of several days after dosing.

We thank Mr T M Weight for his statistical analysis 
and Mrs $\mathbf{J}$ Hewitt and Miss M Hamilton for their excellent technical help.

\section{References}

${ }^{1}$ Clarke DG, McElligott TD, Westonhurst E. The toxicity of paraquat. $\mathrm{Br} J$ Ind Med 1966;23:126-32.

${ }^{2}$ Murray RE, Gibson JE. A comparative study of paraquat intoxication in rats, guinea-pigs, and monkeys. Exp Mol Pathol 1972;17:317-25.

${ }^{3}$ Butler $\mathrm{C}$, Kleinerman $\mathrm{J}$. Paraquat in the rabbit. $\mathrm{Br} \mathbf{J}$ Ind Med $1971 ; 28: 67-71$.

${ }^{4}$ Mehani S. The toxic effect of paraquat in rabbits and rats. Ain Shams Med J 1972;23:599-601.

${ }^{5}$ Restuccia A, Foglini A, DeAlentis Nannini D. Paraquat toxicity for rabbits. Veterinaria Italiano 1974;25:555-65.

- Kimbrough RD, Gaines TB. Toxicity of paraquat to rats and its effect on rat lung. Toxicol Appl Pharmacol 1970; 17:679-90.

${ }^{7}$ Brooks RE. Ultrastructure of lung lesions produced by ingested chemicals. 1 Effect of paraquat on mouse lung. Lab Invest 1971;25:536-43.

${ }^{8}$ Vijeyaratnam GS, Corrin B. Experimental paraquat poisoning: a histological and electron-optical study of the changes in the lung. $J$ Pathol 1971 ;103:123-9.

${ }^{9}$ Modee J, Ivemark BI, Robertson B. Ultrastructure of the alveolar wall in experimental paraquat poisoning. Acta Pathol Microbiol Scand 1972;80:54-60.

10 Wasan SM, McElligott TF. An electron microscopic study of experimentally induced interstitial pulmonary fibrosis. Am Rev Resp Dis 1972;105:276-82.

${ }^{11}$ Gaultier M, Bescol-Liversac J, Frejaville JP, Leclerc JP,
Guillam C. Anatomo-clinical and experimental studies of intoxication by paraquat. Sem Hop Paris 1973;49: 1972-87.

${ }^{12}$ Smith P, Heath D. The ultrastructure and time sequence of the early stages of paraquat lung in rats. $J$ Pathol 1974 ; 114:177-84.

${ }^{13}$ Sykes BI, Purchase IFH, Smith LL. Pulmonary ultrastructure after oral and intravenous dosage of paraquat to rats. J Pathol 1977;121:233-41.

${ }^{14}$ Smith LL, Rose MS. A comparison of paraquat and diquat on the water content of rat lung and the incorporation of thymidine into lung DNA. Toxicology 1977;8:223-30.

${ }^{15}$ Gage JC. Toxicity of paraquat and diquat aerosols generated by a size-selective cyclone. Effect of particle size distribution. Br J Ind Med 1968;25:304-14.

${ }^{16}$ Seidenfeld JJ, Wycoff D, Zavala DC, Richardson JB. Paraquat lung injury in rabbits. Br J Ind Med 1978;35: 245-57.

17 Zavala DC, Rhodes ML. An effect of paraquat on the lungs of rabbits: its implications in smoking contaminated marijuana. Chest 1978;74:418-20.

${ }^{18}$ Daniel JW, Gage JC. Absorption and excretion of diquat and paraquat in rats. $\mathrm{Br} J$ Ind Med 1966;23:133-6.

19 Enna JS, Schanker LS. Absorption of saccharides and urea from the rat lung. Am J Physiol 1972;222:409-14.

${ }^{20}$ Smith LL, Wyatt I, Rose MS. A comparison of the uptake and elimination of paraquat in rat lung slices with that "in vivo." Industrial and environmental xenobiotics 1978; 135-40. (Excerpta Medical International Congress series No 440.)

${ }^{21}$ Zavala DC, Rhodes ML. Selective bronchial catheterisation for the study of experimental lung damage in the rabbit. Proc Soc Exp Biol Med 1973;144:509-12. 